\title{
Tiyatroda Ekspresyonizm ve Bir Oyun Örneği: Machinal (Mekanik)
}

\section{Expressionism in the Theatre and an Example of a Play: Machinal}

\section{Özgür YETKİNOĞLU ${ }^{1}$ (1)}

'Sanatta Yeterlik Öğrencisi, İstanbu Üniversitesi, Devlet Konservatuvarı, Sahne Sanatları Bölümü, Tiyatro Anasanat Dalı, İstanbul, Türkiye

ORCID: Ö.Y. 0000-0003-1750-7724

Sorumlu yazar/Corresponding author: Özgür Yetkinoğlu,

Istanbul Üniversitesi, Devlet Konservatuvarı, Sahne Sanatları Bölümü, Tiyatro Anasanat Dalı, İstanbul, Türkiye

E-posta/E-mail: ozgryet@hotmail.com

Başvuru/Submitted: 11.03 .2020 Revizyon Talebi/Revision Requested: 16.05.2020

Son Revizyon/Last Revision Received: 18.05.2020

Kabul/Accepted: 21.05 .2020

Online Yayın/Published Online: 04.06.2020

Atıf/Citation: Yetkinoglu, O. (2020). Expressionism in the theatre and an example of a play: Machinal. Konservatoryum -

Conservatorium, 7(1), 1-23. https://doi.org/10.26650/CONS2020-0002

\section{öz}

$\mathrm{Bu}$ makalede ekspresyonist sanatın, sanatçının nesne karşısında içsel tutumlarını dışavurumu ve bunun tiyatro sanatında parçalı yazım tekniği, çeşitli ses efektlerinin sahnelemede önem arz etmesi ve toplumsal düzendeki çatlaklara karşı çıkış bağlamında Sophie Treadwell'in Machinal adlı oyunu incelenmiştir. Oyunun anlatım tekniği açısından gerçeklik yapısını bozması, Treadwell'in vurgulamaya çalıştığı düşünceleri açığa çıkardığı düşünülmüş ve bu sebeple özellikle bu gerçeklikten kopuş anlarının görünür kıldığı faraziyeler, içselleştirilmiş ve sorgulanmamış halde kabul edilmesine karşı yeni bir bakış açısı oluşturmanın yolları aranmıştır. Metinde, kadın algısının tekdüze ve ikincil oluşunun altının çizildiği anlaşılmıştır. Bu bilgi de yazarın, oyununu feminist perspektiften yola çıkarak alışagelmiş kadın faraziyelerinin gerçekliğini sorgulamak ve belki yıkmak üzere kurguladığı fikrini doğurmuştur. Ayrıca yazar, kadın odaklı bir hikâye anlatırken, kadın ve siyahi, rahip ve erkek eşleştirmeleri yaparak toplumdaki baskın ve öteki karakterleri ortaya koymuştur. Aslında başlı başına sistem eleştirisi olan oyun, sanayileşmenin getirdiği mekanikleșmeyi, insan ruhuna ve davranışlarına da yansıtmış, bu yansıtışı sahne üzerinde aktörlerin kesik hareket ve parçalı bütünlüksüz ve iletişimsiz konuşmalarıyla göstermek istemiştir.

Anahtar Kelimeler: Ekspresyonizm, Sophie Treadwell, Machinal

\section{ABSTRACT}

In this article, Sophie Treadwell's play Machinal is examined in the context of expressionist art as it expresses the artist's inner attitude towards the object. The play is also examined in the light of its fragmented writing technique, and importance is given to various sound effects in the staging which seem to reflect cracks in the social order. The play's disruption of the structure of reality in terms of the narrative technique is considered to reveal the thoughts that Treadwell tried to emphasize, and therefore the ways of creating a new perspective against the acceptance of the postulates made visible by the moments of detachment from this reality are sought. It is understood in the text that the perception of women is uniform and secondary. This also gives rise to the idea that the writer, based on a feminist perspective, was constructed to question and perhaps demolish the reality of conventional female hypotheses. In addition, while the playwright tells a woman-oriented story, she also reveals the dominant characters in society by making pairs of women and African Americans, priests and men. In fact, the play, which 
is a system criticism in itself, reflects the mechanization brought by industrialization to human spirit and behavior and attempts to show this reflection on the stage by means of the actors' interrupted movements as well as their fragmented and distorted speeches.

Keywords: Expressionism, Sophie Treadwell, Machinal

\section{EXTENDED ABSTRACT}

Expressionism is an art that shapes the experiments that lie deep within a person. When emulation to nature is denied, stylistic variations are not important. Art is there to ensure that the pressures created by daily, random, psychological, and rational facts are resolved and to re-connect with personal creativity and with an imaginary driving force.

The historical period of 1910-1925 in Germany was shaped by pre- and post-war events.

It was influenced by the mental depression of the period, and the lack of creative power brought by industrialization led to new forms of discoveries. The subject and form chosen by the expressionists aimed to destroy the idea that "humans had become machines'. The solidarity of all "others" was advocated.

Expressionism in theater art derives its strength from playwrights who express their own internal crisis and the cracks in society which they encounter. This movement shows itself in a different way of writing. Linear time flow and meaningful conversations seen in realistic plays are disrupted. While formal speeches are not completely left out, there are fragmented dialogues, disjointed words and repetitions that come out with the adoption of the scream feature.

In the staging of such plays, attempts are made by means of all kinds of elements to destroy reality. The plays do not progress according to the cause-effect relationship and any excess is removed from the scene. A stack of decor is not required and there is an affordable asymmetrical scene concept in the icon. Light is used as an important factor in symbolizing and creating tension.

Sophie Treadwell's Machinal was inspired by the real trial story of Ruth Snyder who killed her husband with her lover Judd Gray. The play is the spiritual expression of women being socially positioned as secondary beings after men. In the play, in which feminism is the dominant theme, Treadwell questions many claims such as a woman needs a man to live in normal material conditions, marriage is a material institution, the married woman should be ready for sex at any time, she should love the baby she gave birth to, and sensual pleasure is evaluated differently between men and women. The play 
reflects on the stage the industrialization of the period and is a reflection of the monotonous working life of employees whose job description is specified by their companies. The playwright portrays this mechanically enriched life by means of the actors' disrupted actions to disintegrated forms of speech. In addition, the expressionist style of each scene is supported by its own music or dominant sound effects.

The play consists of nine separate scenes. In keeping with the expressionist style arrangement, the change of scene in different places aims to be accomplished with minimal decor. The scenes take place in the following independent situations: 1- At work, 2-At Home, 3-Honeymoon, 4-Maternal, 5-Prohibited, 6-Intimate, 7-Domestic, 8-The Law, 9-A Machine.

Every scene is the reflection of an idea. The events in the play destroy the socially accepted postulates. The ideas portrayed in the scenes are as follows: In the first scene, the working person has been mechanized. In the second scene, it is not love but a man with good financial strength who is ideal for marriage. In the third scene, the married woman must be prepared for sex. In the fourth scene, the woman is happy that she gave birth to a baby. In the fifth scene, concepts such as cheating, abortion, homosexuality are depicted as immoral. In the sixth scene, love brings freedom. In the seventh scene, acquiring property by being in debt becomes the status indicator of a person. In the eighth scene, laws are result oriented. News necessarily includes comments. In the ninth scene, freedom is not possible for any 'others'.

When we look at the formal arrangement of the play, the fragmented speech structure is dominant in the first scenes and realistic writing techniques based on a cause-effect relationship is disrupted. Realistic form features are more common in the last scenes. Although there are fragmented dialogues, they are less than in the first scenes. However, this does not cause the play to lose its expressionist character. The newspaper headlines, which are read independently from each other in the seventh scene, and the intervention of different news commentaries of the journalists during the eighth scene, appear as strengthening elements of this structure.

Machinal questions all kinds of topics from the woman's sexuality to work life, from material life to sexual pleasure, from social freedom to motherhood, and the woman is presented as an oppressed biological-social unit. In so doing, Treadwell uses many of the mentioned staging elements and writing techniques that could destroy realistic theater. 


\section{Giriş}

Empresyonizmden uzaklaşma ve ona gelen tepkilerle şekillenen ekspresyonizmde, geçici olan her şey sadece simgesel bir görüntüdür. Önemli olan düşünce, sanatçının kendi yaşamı, dış dünyanın kendi üstünde bıraktığı izlenimleri, onun kendi içinden geçirerek dışavurumudur. Sanatçı, içindeki doğa görünümlerini sanat eserine iletir.

1910-1925 Almanya'sının bir parçası olarak düşünülen ekspresyonizm, I. Dünya Savaş1 öncesi sanayileşmenin getirdiği, makineyi yok etme fikri ile aileden orduya, kurulu her türlü düzene karşı bir ayaklanmadır. O dönemin sanatçıları, aşağılananlar, düzen kıyısında yaşayanlar, ezilenler, akıl hastaları ve yoksulların, yani her türlü ötekinin dayanışmasını savunmaktaydı. Savaştan sonra ise ekspresyonist kuşak, insanın yükselişini, onun içten yenilenmesinde görüyordu. Bu bağlamda, daha uçlara gitmeden toplumsal/biyolojik en küçük birimlerden olan cinsiyet ayrımından, 'kadın'ın öteki oluşunu ele alarak Machinal oyununu kaleme alan Sophie Treadwell, 1927'de elektrikli sandalyede idamı gerçekleştirilen ilk kadın olan Ruth Snyder'in âşığı Judd Gray ile birlikte, kocasını öldürmesinin gerçek hikâyesinden esinlenmiştir. Treadwell'in, davaya dahil olmasa ve Ruth ile röportaj yapmasa da mahkemeyi izlediği bilinmektedir. Treadwell, 1928'de prömiyerini New York Plymouth Theatre'da yapan oyununun, ısrarla sıradan bir kadın hikâyesi olduğunu ve her kadının ortak acısını anlattığını beyan etmiştir.

1920'ler düşünüldügünde, oyun, Ruth'un hikâyesi ile olan benzerlikleriyle sınırlı kalmayacak kadar geniş bir yapının içeriğini sunar. Ruth, Treadwell için bir çıkış noktasıdır. İlk defa bir kadın, elektrikli sandalyede hem de tamamı erkek olan bir jüri tarafından idama mahkûm edilmiştir. Bunun, ekspresyonist oyunlarda olduğu gibi yazarın benliğinde bir etki yaratması ve bu içsel etkinin dışavurumu olarak tezahür ettiği bilgisinden yola çıkılmıştır. Oyunun en küçük parçalarına bölünerek analiz edilmesi hedeflenmiştir. Böylece, yaşamın içinde yer ederek sorgulanmadan doğru kabul edilmiş faraziyeler, sorgulanmaya ve görünür kılınmaya çalışılmıştır. "Görünür kılmak" (Moran, 2014, s. 66) Althusser'in edebi metin eleştirisinde, "üretim olarak sanat" (Moran, 2014, s. 64) eleştiri kuramının kavramıdır. "İdeoloji [...] maddîdir, çünkü kilise, aile, okul ve parti gibi kurumların maddî pratiğinde üretilir. Bu kurumlara Althusser 'ideolojik aygıtlar' demektedir. Bunların bir görevi, sınıf yapısının toplumdaki bireyler tarafından benimsenmesini sağlayacak bir ideoloji üretmektir" (Moran, 2014, s. 65). Treadwell'in Machinal oyununun da benimsenen ideolojileri görünür kılmak maksadıyla yazıldığı düşünülmektedir. Althus- 
ser'in eleştiri kuramı, her metne uygulanarak, benimsenmiş ideolojileri açığa çıkarabilecek bir kuram olsa da; Machinal oyununda, yazarın da özellikle sorgulanmayan faraziyeleri görünür kılma amacı sezilmektedir. Çünkü Treadwell kadınlık, erkeklik, annelik, evlilik, cinsellik, iş hayatı, adalet sistemi, medya gibi kurumları sorgulamaktadır. Oyun, biçimsel olarak ekspresyonisttir. Analizde, oyunda yer alan ekspresyonist tiyatronun öğeleri saptanmaya çalışılmıştır. Saptanan öğelerin, faraziyeleri görünür kılmadaki etkileri araştırılmıştır.

\section{Ekspresyonist Sanat}

Ekspresyonist sanat yapıtları, bir kuşağın genel duygularının tüm yönleriyle fışkırdığı inançlarının (Richard, 1999, s. 7), sanatçının öznel duygu ve düşüncelerinin son derece özgür biçimler içinde, mantık bağlantısı bozularak ve parçalanarak, gözle görülenin değil zihinde yaşananın ifadesidir (Şener, 2008, s. 248-249). Bunun için de geçmişle bağlantılı olan etkilere yeni bir şekil vermek için deneysellik benimsenmiştir (Smith, 1987, s. 15). Yvan Groll, teknik olarak belli bir programı benimseyen sanatçıların oluşturduğu bir okuldan bahsetmenin olanaksız olduğunu vurgulamıştır. Ekspresyonizmin entelektüel alanda tıpkı salgın bir hastalık gibi her şeyi etkilediğini; yalnız şiir ve resmi değil, düzyazım, mimarlık, tiyatro, müzik, bilim, üniversite ve okul reformlarını da yönlendirdiğini belirtmiştir.

Ekspresyonizm kelime olarak, Almanya'da Wilhelm Worringer'in 1911'de Abstraction and Emphaty (Soyutlama ve Özdeşleyim) isimli kitabında yer almasıyla kullanılmaya başlandığı ileri sürülse de başka bir görüş, Paul Cassirer'in 1910'da, Pechstein'in resmi önünde, tablonun bir ekspresyonizm örneği olduğunu söylemesiyle yayıldığıdır (Richard, 1999, s. 7). Ayrica Henri Matisse, 1909 yılında Note d'un Peintr (Ressamin Notlar1) isimli yazısında; "Her şeyin üstünde kendime dışavurum (ekspression) için bir yol arıyorum" (Richard, 1999, s. 8) diyerek bu terime katkıda bulunduğu yadsınamaz.

Berlin Sezession'un 1911'deki Nisan-Eylül sergisinde Braque, Derain, Kees van Dongen, Dufy, Friesz, Manguin, Marquet, Picasso ve Vlaminck'in yapıtları sergilenmiştir. Serginin kataloğunda bu isimler Ekspresyonist olarak sunulmuştur. Ekspresyonist sözcüğü böylece tam manasıyla halk önüne çıkmıştır (Richard, 1999, s. 8).

Herbert Kühn ise ekspresyonizmin estetik anlayışını ortaya koymaya çalışmıştır. Ekspresyonizme göre amaç, tanıtılan nesne değildir. Nesne dış dünya ile somut olanla sınırlandırıldığı için, artık yansıtılan nesne anlamından koparılmıştır. Anlatılmak istenen o 
nesne değildir. Yansıtma denilen, ancak anlatılanı anlamak için bir çağrıdır. Anlatılmak istenen şey resim, şiir ve tiyatro oyununun ötesinde başlar (Richard, 1999, s. 9). Yazarların hissettiği yabancılaşma ile bir dünya kardeşliği ve ruhsal değerler yaratma tutkuları arasında çelişki vardır (Smith, 1987, s. 14).

Ekspresyonizm makineleşmeye ve merkezileşmeye karşı, insan yararına bir haykırış olduğu için sosyalizmden ayrı bir ekspresyonizm düşünülemez. Bu sebeple pek çok ekspresyonist sanatçı sosyalist eylemlerin içinde yer almıştır. Yvan Goll: "Ekspresyonizm devrim ve savaşın edebiyatıdır [...]" (Richard, 1999, s. 20) demiş̧ir. Savaş sonras1 ekonomik bunalım ve parasal baskıların etkisiyle içsel yaratıcılı̆̆ın; uyumsuz ve ayarsız olma adına saldırgan bir kendini beğenmişliğe dönüştüğü söylenebilir. Bu dönüşümün ortaya çıkardığı yapay yönelimler halkta şok yaratmanın ötesine gidememiştir.

Ancak, her ne olursa olsun gücü zayıflasa da ekspresyonizm 1960'larda yeniden ortaya çıkmıştır. Hiçbir akım çağının toplumsal ve bireysel sorunlarıyla bu denli iç içe olmamıştır. Bu özelliği, ekspresyonizmin çağın zıtlıklarını zorlayarak onu yenmeyi yılmadan denemesinden gelir. Çünkü, akımdan ziyade akımları içine aldığı, onlara uygulanabilen tarihsel bir öncüdür (Richard, 1999, s. 22).

\section{Tiyatroda Ekspresyonizm}

Gerçekçi tiyatro anlayışına karşı çıkan ekspresyonist tiyatroda, yeni biçim arayışıyla oyun yazarlı̆̆ından yönetmenliğe, yeni ve çarpıcı teknikler geliştirilmiştir. Sanatçı öznel duygu ve düşüncelerini ifade ederken; konuşmaların normal akışı parçalanmış, olayların ve sahnelerin mantıklı bağlantısı ile sahne görüntüsünde biçimler çarpıtılmıştır. Ön plana yazarın ve yönetmenin ortaya koyacağ düşüncenin geçmesiyle oyun kişileri simgesel tiplere indirgenmiştir (Şener, 2008, s. 248). Tiyatro sahne sanatı olmasına rağmen, dönemin anlayışı, sahnelemenin yanı sıra en çok, yazılan tiyatro metinleri üzerinden analiz edilmeye çalışılmıştır. Ekspresyonist dönemin yazarlarının sosyal konumları ve estetik anlayışları arasında farklılıklar vardır. Bazılarının aktivist yönü sanat yönünün önüne geçmiştir (Richard, s. 157). Bilinçaltı, tutku ve duygunun öznel ifadesinin de etkisiyle (Şener, 2008, s. 250) biçimlerin yazardan yazara farklılaşmasından dolayı, tiyatroda bu akımı oluşturan ana öğe, üslupların ayrışması olarak görülebilir (Richard, 1999, s. 157). Bu üslup yenilikleri, daha çok Almanya'da doğup yayılan, savaşın etkisiyle şekillenen arayış biçimleridir. Örneğin, savaşın Avrupa gibi etkilemediği Amerika'da ekspresyonizm daha çok 1925 'ten sonra etkisini göstermiş ve 30'larda büyük ekonomik krizden 
sonra ivme kazanmıştır. Çevre etkileriyle bütünleşmeyen bir ekspresyonizmden söz edilemez. Makineleşmenin yarattığı bunalım Amerika'da yoğun yaşansa da savaşın etkisi Avrupa'ya göre daha az hissedilmiştir. Amerika'nın ekspresyonizmden biçimsel, sanatsal kaygı açısından etkilenmesi daha ön plandadır (Smith, 1987, s. 9-10). Yani yaşananlardan ziyade, dönemin ruhu, sanatın yeni bir akımdan etkilenmesine yol açmıştır.

Tiyatroda ekspresyonizme bir çerçeve çizmeye çalıştığımızda ise öncelikle dahil edeceğimiz etmen çı̆̆lık olacaktır. Estetik bir olgu olarak çı̆̆lık, toplumsal duruma bir karşı çıkışı simgeler. Çığlıkla yaratılan heyecan, içine düşülen karanlık dünyanın dışavurumudur. Yazarınsa ruhsal yalnızlığının, toplum dışı kalışının çığlığıdır. Fakat bu çığlıkların zaman zaman bir çılgının sayıklamalarına dönerek, bağlamdan uzaklaşarak yansıtıldığı da görülmüsşür.

Ekspresyonizmde "amaç, insanı toplumsal çevresinden, hatta kendisinden bile soyutlamaktır. Geriye yalnız Tin kalır. [...] bağımsız bir 'Ben’ özlemi içinde şaşırtıcı bir etki bilinçli olarak aranır” (Richard, 1999, s. 158). Yazarın/sanatçının ‘ben’ olarak, insanlıkla mesafesinin sezgisel ifadesi dramanın temelini oluşturur ve liriklik katar (Smith, 1987, s. 14). Düşler ve karmaşası, iç itimler, yaşama yön veren gizli güçler olarak önem kazanmıştır. Ruh bilimi ve psikanalizin etkisiyle dış baskıların kaldırılması amaçlanmıştır.

Yozlaşan toplumun sorunlarını deşmek, bilinçaltının korkunç karmaşasını eşelemekle mümkün olacak ve bu, yeni bir toplumsal uyumu da beraberinde getirecektir. Burada bir onarma ülküsü söz konusudur. "Kan dökücülük sanki bir alışkanlık olmuştur. Öldürme, diri diri gömme, intihar, işkence sahneleri yazarın toplumsal ve bireysel yozlaşmaya karş1 protestosudur" (Şener, 2008, s. 250). Onarımda bir diğer değer sevgi özlenmektedir. Bu yönüyle de hümanist ve ütopyacıdır (Şener, 2008, s. 251).

Tiyatro tarihi açısından incelendiğinde ise ekspresyonist tiyatro, gerçekçi tiyatro ve mutlu son ile biten melodramların geleneksel değerlerin sırtının sıvazlamasına bir başkaldırıdır (Şener, 2008, s. 250). Şener'e göre (2008, s. 249), ilk ekspresyonist oyun Kokoschka tarafından yazılmıştır. Lionel Richard, August Strindberg'in Şam Yolu (1898) oyununu ilk ekspresyonist oyun sayar (Richard, 1999, s. 159). Ancak 19. yüzyılın ikinci yarısında ekspresyonizm henüz akım olarak isimlendirilmemiştir.

Richard (1999, s. 162), "Toplum en açık biçimde komedilerde yansıtıllı" demiştir. Ekspresyonist tiyatro döneminde komedi oyunu yazılmamıştır. Politik görüşlerini oyunları- 
na yansıtmaya çalışan yazarlar da hayal kırıklığına uğrayarak nihilizme sürüklenmişlerdir. $\mathrm{Bu}$ nihilizm ise yaratıcı güce katılarak oyunlara yansıtılamamıştır. Savaş sonrası "dokunaklı bir barışçıllı̆̆ı aşamamıştır" (Richard, 1999, s. 162-163).

Sahnelemede yenilik getiren anlatım yöntemleri incelendiğinde, ekspresyonist akımın belli bir manifestosu olmamasına rağmen, geleneksel tiyatro biçimlerini kökünden sarsmıştır. Olay ya da karakter tiyatrosuna karşı çıkış olan ekspresyonist tiyatro, sahnenin merkezine düşünceyi getirmiştir. Sahnede eş zamanlı olaylar neden-sonuç ilişkisine göre ilerlemek zorunda değildir. Soyut ve kavramsal tiplere, yani simgeye dönüşen baş karakterin sunduğu düşünce, parçalanmış sahne yapısıyla desteklenmiştir. Bir sahneleme reçetesi olmasa da esas olan tedirginlik ve başkaldırı ruh durumunu yansıtabilmektir. Artık konuşma ile eyleme, tiyatroda yerini hareketlerle verilen makineleşme tasvirlerine bırakmıştır. Bütünlüğün kesilerek sekteye uğratılmasıyla, jest ve mimlerin ön plana çıktığı, tarzı gereği abartarak stilize oynama, esasen devinimin hakim olduğu bir yapıyı yaratmıştır (Şener, 2008, s. 252). $\mathrm{Bu}$ devinimi sağlayan ise karşıtlıklardır. "Gerçek ile fantazi, Tanrısal olanla dünyadaki vahşet, lirizm ile pornografi, kısa anlatım ile uzun monolog, düzyazı ile koşuklu yazı yanyana getirirlir. [...] Karşıtlık, devinim, ivedilik, dünyanın anarşik durumunu sergiler” (Şener, 2008, s. 252). Bu anlamda sahnelemede günlük olağan gerçek bozulmuştur. İç gerçekliğin dışa yansıması, renkler (1şık) yoğunlaştırılarak çarpıtılmıştır. "[...] Nesnelerin biçimini bozmak, doğa üstü gölgeler yaratmak ve patetik gerilimi arttırmak amacını taşır" (Richard, 1999, s. 199). En çok kullanılan tekniklerden biri, alttan 1şık vererek nesneleri ve oyuncuları devasa boyutlarda göstermektir. Renklerin zitlıklarından yararlanılır. Sadece 1şıkla değil aynı zamanda kostüm ve oyuncuların ten renkleriyle (beyaz, siyah ya da mekanik) de zıtlık verilmeye çalışılır. "[...] Hileli perspektifleri, yarım kalmış öğeleri, dikeylerin yerini alan eğik çizgileri, hesaplı bir asimetriyi, anlatımlı çizgileri buluruz dekorda" (Richard, 1999, s. 196). "İçe doğru eğilimli duvarlar, iskelet görünümlü ağaçlar, makine gibi devinen insanlar, bir karabasan havası yaratır. Mezardan çıkan ceset, kafasını sırtındaki torbada taşıyan adam gibi görüntülerle yüreklere korku salınır” (Şener, 2006, s. 253).

Sahnede gereksiz dekordan kaçınılmalıdır. Dekor yığını asla istenmez. Dekor gösterdikleriyle değil ima ettikleriyle etkilidir. Ses ise korkutucu bir unsur olarak; kentsel mekanik, kaos kent ya da mezar havasını yaratacak bir efekt yöneliminde simgesel bir araç olmuştur.

Tüm bu yeniliklere rağmen, ekspresyonist oyunlar kendisini öyle ciddiye alıyordu ki yazarın düşüncesini ön plana çıkarmak için yazınında mizah barındırmaması ve sıkıcıı- 
ğ1 aşma çabası olmaması seyirciyi yakalayamamıştır. Ayrıca politik bir dönemin baskı koşullarında seyircinin bu tarz özgürce ifadeler sergileyen oyunlara gitmekten çekindiği de bilinmektedir (Smith, 1987, s. 9-10).

Kısacası hangi tiyatro metni olursa olsun ekspresyonist biçimde sahnelenebilir. Bu, yazılan metni birebir sahneye taşımak değil, sahnelemede metnin öne çıkardığı düşünceden yararlanmaktır. Eserin anlatım gücünü en üst seviyeye çıkartmak, seyirciye dolaysız ulaşabilmek, sahnenin öğelerini -oyuncu, dekor, 1ş1k, ses- ruhun veya düşüncenin çığl1ğını sahneye taşımak için, her türlü teknik seferber edilir ilkesi hakimdir.

\section{Bir Ekspresyonist Tiyatro Örneği: Machinal}

1885 'te Stockton California'da doğan Sophie Treadwell (Dickey, 1999, s. 66), yedi oyunu Broadway'de sergilenmiş fakat en çok Machinal adlı oyunuyla ün kazanmış gazeteci, oyun yazarı ve tiyatrocudur. Daha önce pek çok gerçekçi tarzda oyun yazsa da 1920'lerde New York'ta esen ekspresyonist rüzgarının da etkisiyle yeni bir teknik deneme yoluna gittiği düşünülmektedir (Dickey, 1997, s. 176-177). Genel olarak kadının özgürlük ve eşitliği için kişisel çabalarına engel olan modern toplumun izini sürer. Scribe’ın iyi kurulu oyun düzeninde ya da Aristotelyen tarzda eser vermemesi Treadwell'in, formal yapının her zaman üstüne çıkma yaratıcılığı için yaptığı revizyonlarından kaynaklanmaktadır. O, kendi deyimiyle de nasıl yazacağı üzerine odaklanmaktadır. Kendisinden oyun metninin ne olduğunu ya da olmadığını öğrenmek isteyen öğrencilerinin hayal kırıklığına uğrayacaklarını söyler. Çünkü oyun yazma konusunda yaptığından daha azını bildiğini beyan etmiştir (Dickey, 1999, s. 68).

Bywaters (1990), Machinal ile ilgili değerlendirmesini şöyle ifade etmiştir:

\footnotetext{
“Sophie Treadwell'in feminizm görüşü ile radikal yaklaşımla kaleme aldığı Machinal oyunu; tekrarlanan diyaloglar, ses efektleri, kısa sahne, çarpıtılmış içsel ve dışsal gerçekliklerle kullandığı ekspresyonist teknikler, Edvard Munch'un çarpıklığına benzer bir yaratıcılı̆̆ı, sıradan bir genç kadının çaresizlikten cinayete sürüklenen yolculuğunu resmederek yazılmıştır. [...] Çarpıcı bir suçun temelinde Treadwell, ekonomik ve sosyal baskı sonucu işvereniyle evlenmeye zorlanan genç bir kadının hikayesini inşaa eder. Âşı̆̆ı Meksika'ya döndükten sonra duygusal olarak her şeye kendini kapatan kadın, artan ıstırabı ile içine taşlar doldurduğu bir şişeyle kocasının kafasına vurup öldürür. Bu öldürme şeklini de âşığından öğrenmiştir. Mahkemede, yasak âşığının hüküm giymekten kurtulmak için yazdığı bir mek-
} 
tup ortaya çıkınca genç kadın suçunu itiraf eder. Oyun genç kadının idamıyla sona erer”' (Bywaters, 1990, s. 98).

Treadwell, oyunu yazarken, kocasını öldüren Ruth Snyder'in davasına ince göndermelerde bulunmuştur. Ruth'un görünümüne çok özen göstermesi, ölümü beklerken bile saçını boyaması ve bakımını yapmasina oyunun final sahnesinde gönderme yapılır. Ruth'un hapishanede bir kaç kez bayılması ve âşığının, kocasına saldırdığında bayılması, oyunun ilk sahnesinde Helen'in metroda bayılmak üzereyken metrodan inip hava alma ihtiyacı hissetmesiyle özdeşleştirilir. Elbette Ruth da Helen gibi ekonomik gerekçelerle kendinden yaşça büyük patronuyla evlenmiştir (Jones, 1994, s. 489). Dönemde feminist etkinlikler başlamış olsa da kadına biçilen ana akım rol hala iyi bir evlilik yapmak ve onu yürütmektir. Endüstrileşmeyle modern çalışma hayatına dahil olan kadının eşitliğinden söz etmek pek de mümkün değildir. Şu zamanda feminizm ana akım görüş olarak algılanabilir. Fakat 1920'ler dönemi düşünüldüğünde, Treadwell belki de farkında olmasa da modern kadının cehennemini yazarken, amacının ötesinde çözümler sunmuştur. Bu çözümleri bugünkü okumalarla elde etmek mümkün olmuştur. Hala ana akım kadın algısı, ‘kadın'ı evliliği üzerinden tanımlarken, Treadwell o dönemde bu algıyı yıkmıştır (Tancheva, 2003).

Yazar, toplum mekanikliğinin sebep olduğu ataerkil düzenin yarattığı kadının, duygu ölümünü yansıtmıştır. Ancak, okunup sahnelenince, bu duygu ölümüne koşut olarak sunulan pek çok toplumsal değişimin de habercisidir. Bu sebeple oyunun sahne sahne ortaya çıkardığı ataerkil toplumsal faraziyeler ile analizi ve yorumu, diğer bir değişle parçalı oyunun anlarını ve verili her öğesini daha da parçalarına ayırarak analizinin gerekliliği düşünülerek araştırma şekillendirilmiştir.

\section{Machinal Oyununun Ekspresyonist Tiyatro Bağlamında Analizi}

\section{Bölüm-1: İșe (to Business)}

Perde açılana kadar mekanik ses vızıltıları işitilir. Telefon, hesap makinesi, daktilo, uyarı sesi, zil sesi ve takırdama sesi duyulur. Sahne açıldığında ofis çalışanları stenograf, sayman, dosya memuru ve sekreterin ${ }^{2}$ mekanik hareketler ve konuşmalarla işlerini yaptıkları görülür. Burada amaç, endüstrileşen Amerika'nın kaos atmosferini yaratmaktır.

1 İngilizce çevirisi makale yazarı tarafindan yapılmıştır.

2 Oyunda telephone girl olarak geçen, görevi sadece telefona cevap vermek olan bu karakter, makalede 'sekter' kelimesi ile ifade edilmiştir. 
Çalışanların, iş arkadaşları Helen hakkındaki konuşmalarının, iş sürerken ve az önce bahsedilen rahatsız edici seslerle paralel ilerlemesi, Helen'in çepeçevre sarıldığı stresi yansıtmak amacıyla endişeli ve sinir bozucu bir hava ile yaratılmak istenmiştir. Helen'in iç dünyasına ilk adım, bu seslerin yarattığı atmosfer sayesinde atılacaktır.

Şirketin başkan yardımcısı George H. Jones, sekreter kızdan telefonda Helen'in henüz gelmediğini öğrenir. Ofis çalışanları Helen'in, George'u avucunun içine aldığı ile ilgili dedikodu yaparken, dayanamayıp içeri giren George, tekrar Helen'i sorar. Ona bir mektup yazdırmak istemektedir. Stenografın yazma teklifini reddeden George, her şeyin tek tek ve doğru düzgün yapılması gerektiğini söyleyerek odasına geçer.

Aceleyle ve telaşlı bir şekilde ofise ulaşan Helen'e arkadaşları bu gidişle işini kaybedeceğini söylerler. Helen ise metroda insanların arasında havasızlıktan ölecek gibi olduğu için inmek zorunda kalmıştır ve bu yüzden geç kalmıştır. Bu aceleyle sahneye dalış ve metronun sıkışıklığıyla klostrofobik iş saati yolculukları, Helen'in şehir hayatına uymayan bir yapısı olduğunu; ölecek gibi olması, çevreyi bir tehdit olarak algıladığını gösterir.

Helen, George'un ofisine gidince iş arkadaşları dedikoduya devam ederler. "Evlenecekler mi? Çoktan yattılar mı?"3 (Treadwell, 1993, s. 7) gibi sorular mekanik ve kesintili bir halde ve parçalanmış cümleler arası telefon cevaplamaları vs. ile devam eder.

Helen, George'un odasından ofise dönünce, çalıştığ makine bozuk olduğu için çalışamayacağını söyler. $\mathrm{Bu}$, ruhsal yaşamı ile iş yaşamını birbirinden ayırdığının göstergesidir. Bu duruma kayıtsız kalması ve tamir edilmesi için hiçbir şey yapmaması onun gerçeklikten kopan ruhsallığını sunar. Stenograf ise tam tersi bir durumda, işi ile günlük hayattaki konuşmalarının birbirine girmesiyle, mekanik endüstrinin yuttuğu bir tiptir.

Ofis çalışanları Helen'e, George'un evlenme teklifini sorarken, George içeri girer. Helen'e mektubu bitirip bitirmediğini sorması sırasında, onu omuzlarından tutmasılyla Helen irkilir. Henüz bitirmediğini söyleyerek mektupları sınıflandırdıktan sonra yazacağını belirtir. George'un çıkmasıyla sekreter kız, adamın onu çimdiklediği için mi irkildiğini sorar. Helen çimdiklemediğini sadece dokunduğu için irkildiğini söyler. Bunun üzerine evlenme teklifini kabul etmemesi gerektiği ama aksi halde kovulacağı, kabul ederse hiç çalışması gerekmeyecek bir hayatı olacağı üzerine yorumlar yapılır. Burada yazar, evliliğin yararcı bir kurum olduğunu, duyguların sadece sekreter kız tarafindan önemsense

3 Oyun repliklerinin çevirileri makale yazarı tarafından yapılmıştır. 
de diğerleri tarafından hemen sohbet dışı bırakıldığını göstermektedir. Bu manada demek ki evlilik de sorgulanması gereken bir kurumdur. İçi boşalmıştır.

Ofisin mekanik sesleri devam ederken, bu kaosta Helen'in kendi başına sayıklamalar1 ${ }^{4}$ duyulur. Helen rahat yaşamı, ruhsal yok oluşuna tercih edecek midir? Fakat kimse Helen'i duymaz, bu içsel bir çığlığın, sahnede kalabalıklar içindeki yalnızlığın vuku bulmasıdır.

\section{Bölüm-2: Evde (at Home)}

Helen, annesiyle mutfak masasında otururken yine atmosferde şehrin bunaltıcı sesleri duyulmaktadır. Apartman gürültüsü, dışardan geçen insanların yüksek sesleri ve radyo sesi arasında annesi, daha fazla patates yemesini ve minnet etmesi gerektiğini söylerken, Helen de söze girmeye çalışmaktadır. Aralarındaki mesafe kısa olmasına rağmen düzgün bir konuşma yürütemezler. Sonunda Helen söze girer ve George'un evlenme teklif ettiğini söyler. Annesi önce, "Başın derde mi girdi?" (Treadwell, 1993, s. 16) diye sorar. Bu, aslında annesinin, hamile kaldığı için gelen bir evlenme teklifi olduğundan şüphelenmesidir. Helen de adamın, kendisinin ellerine âşık olduğunu söyler. George'un başkan yardımcısı olduğunu öğrenince bu sefer annesinin tüm şüpheleri dağılır. Adamın kazandığı parayı tahmin etmeye çalışır ve Helen'e bakıma muhtaç bir annesi olduğundan bahsedip etmediğini sorar. Bu sahnede oyunun geneline yayılan evliliğin çıkar sağlayıcı bir kurum olarak görülmesinin inşasını tekrar görürüz. Treadwell okuyucuya/izleyiciye annenin aşkla ilgili herhangi bir yaklaşım sergilememesi ve evliliğin ancak, yapılan bir hata (hamile kalmak) sonucu ya da finansal destek için, Amerikan'ın kapitalist sisteminin yarattığı ilişki biçimi olduğunu görünür kılar.

Aşık olmadığ i için evlenmeyeceğini söyleyen Helen'e annesi karşı çıkar ve evliliğin finans desteği üzerine bir kurum olduğunu "Așk kıyafet alır mı, karnını doyurur mu, faturaları öder mi?" (Treadwell, 1993, s. 17) sözleriyle yineler. Babasıyla evlenirken âşık olup olmadığını bile hatırlamadığını söyler. Bir anda sahneye hakim olan karı-koca dış sesleriyle, geçmişteki bir konuşma duyulur. Ancak bu anne-babanın genel ilişki yapısını aktarmaktadır. Kocasının öpücük isteğine karşı "Çok aptal görünüyorsun. Bana böyle bakıp öptüğünde ne olacağını biliyorum. Çekil başımdan!” (Treadwell, 1993, s. 18) diyen bir kadının sunumu, aşkın bile evlilikte zorlamaya döneceğinin bir göstergesi gibi

4 “Şişman el”, “dokunma bana”, “evlilik”, "kızlar evlenmeyin”, “çoğu kız evlenir”, "bebek”, "dinlenmek yok”, "metroda sıkışmak", "hava", "iş", "iş yok", "kovuldun” (Treadwell, 1993, s. 11-12). 
görünmektedir. Evliliğin Helen'in umduğu gibi aşk dolu değil, aksine duyguları yıpratıp yok ettiği, bilinçaltı seslerle ortaya konmaktadır.

George ona dokunduğunda kanının çekildiğini belirtmesi üzerine, annesinin sürekli Helen'e "Sen delisin" (Treadwell, 1993, s. 19) demesi, genç kadını çıldırtır ve bir daha bu lafı ederse annesini öldüreceğini söyler. Burada maddi gücü yerinde olanın düzgün insan olduğu faraziyesi görülür. Bu, kapitalizmin bir faraziyesidir. İnsani değerler bile paraya göre belirlenir. Ayrıca Helen'in erkeklerden istemediği bir tavır ya da dokunuş gördüğünde uyanan duygusal rahatsızlığını gösterir. Helen'in sadistik erkek yaklaşımı algısının ilk nüveleri bu dokunuştan bahsedişiyle anlaşılır. Ayrıca annesine kızdığında öfkesini “Seni öldüreceğim!” (Treadwell, 1993, s. 19) diye ifade etmesi, içindeki şiddet dürtüsünü anlamamızı sağlar.

Helen, annesiyle kavgası sonrasında ettiği incitici laflardan dolayı onun gönlünü alır ve bulaşıkları yıkamak için eldiven takar. Annesi kırk yıldır bulaşık yıkarken eldiven takmadığını söylemesi üzerine Helen, "Bana bu eller koca buldu" (Treadwell, 1993, s. 20) demesiyle evlilik teklifini kabul etmeyi düşündüğünü belirtir. Artık Helen, insanların 'ekonomik çıkarın evliliği üreten en önemli unsur' olduğu fikrine boyun eğmiş görünmektedir. Annesinin caz dinlemesiyle sona eren sahne, sahnenin ritminin caz müziğine uygun olması gerektiğini gösterir.

\section{Bölüm-3: Balayı (Honeymoon)}

Mütevazı tanımlanmış (yatak, ayna, sandalye) otel odasına balayı için gelen Helen ve George, George'un odanın ne kadar lüks ve pahalı olduğu konusunda böbürlenmesi ve Helen'in kasinodan gelen gürültülü caz müziği yerine, okyanus manzarası umduğunu söylemesiyle üçüncü sahne başlar. George, Helen'e şapkasını çıkarıp rahat etmesini ve korkmuş göründüğünü, kocasıyla olduğu için hiçbir şeyden korkmaması gerektiğini söyler. Burada evlilik kurumunun daha sarsıcı bir yönünü görürüz. 'Koca', yanında rahat edilmesi gereken, kadının her türlü açıklığını sunması gereken bir kimliktir. Halbuki Helen için George'un sıfatının 'koca' olarak değişmesinin bir anlamı yoktur. O hala aynı adamdır. Ataerkil bir yapılanma ile evlilik, anında sonsuz yakınlaşmayı beraberinde getirmek zorundadır ve sınırlar kalkmalıdır. Helen de bu durumda 'koca'nın istediği gibi davranmak zorunda olan, üretilmiş bir eş olarak konumlanmaktadır.

George'un Helen'i kucağına oturtup sevişmeye başlar fakat; Helen istemez. Helen'i sevişmeye ikna etmeye çalışan George'un "Ne kıpırdanıyorsun, rahatlamayı öğrenmelisin 
küçük kız” (Treadwell, 1993, s. 23) sözü Helen'i daha çok rahatsız eder. Helen banyoya kapanıp üstünü orada değiştirmek ister. George ise "Ben senin kocanım, farkında mısın?" (Treadwell, 1993, s. 24) diyerek çerçevesi çizilen evlilik kurumunun biçilmiş değerleri içinde davranır. Helen'e göre bu sadece bir unvan değişikliğidir. Karı-koca olunmuştur. Ancak; kişilikler, duygular değişmemiştir. Annesini istediğini söyleyerek ağlamaya başlar. Sonrasında Helen'in "Birini istiyorum. Biri gelsin. Herhangi biri!" (Treadwell, 1993, s. 26) cümleleriyle sahne sonlanır.

Buradaki 'Biri gelsin. Herhangi biri’ sözleri ekspresyonist dramanın çı̆̆lık düsturunun bir örneğidir. Bu sözler, Helen'in ruhsal yapısının kocasıyla baş başa kalmalarını kaldıramadığını göstermektedir. Çünkü Treadwell, 'evlilik, birbiri önünde hemen soyunmayı ve yatağa girmeyi gerektirir mi?' sorusunu ortaya atmak istemektedir. Evlilikle beraber bu ne kadar meşrulaşır? Kadının bu duruma hazır olmaması, kocanın 1srarla istemesi, bir nevi ruhsal yıkımın öncülü değil midir? George'un hazır bulunuşu, evliliğin cinsellikle bütünleşik bir kurum oluşu, kadının hazır olmayışını ne kadar denetleyebilmektedir? Elbette George, sevdiği bir kadınladır ve karısına "Korkacak bir şey yok. Kocanlasın" (Treadwell, 1993, s. 22) diyerek onunla empati kuramamakta ve anlam verememektedir. Zaten bu duyguyu anlamasına pek de olanak yoktur. $\mathrm{Bu}$ yine de bir adamın, evlendikten sonra cinselliğe hazır bulunamayan kadını zihnen bir şemaya oturtamamasından kaynaklıdır. Cinsellikle bağdaşmayan evlilik var mıdır? Neden yoktur? Farklı formlar mümkün müdür? Ekspresyonist dramanın, kurumların değerlerini ve bütünleșmiş faraziyelerini sorgulamak için nasıl bir akım yarattığı burada daha net anlaşılabilir.

\section{Bölüm-4: Annelik (Maternal)}

Doğum sonrası hastane odasında geçen dördüncü sahnede hakim olan ses, pencereden gelen 'perçinleyici' seslerdir. Pencereden görülen inşaatın sesi rahatsız edicidir. Helen sessizdir. Hemşire kız doğurmuş olmaktan dolayı mutlu olup olmadığını sorduğunda Helen sessizce başını iki yanı sallar.

Hemşire, Helen'e “Kız olduğu için mutlu değil misiniz? Söyleyecek bir şey yok. Erkekler oğlan ister, kadınlar kız istemelidir" (Treadwell, 1993, s. 27) der. Bu tutumu, anne olmaya sevinemeyen bir kadının algı sınırları dışında olduğunun göstergesidir. Ebeveynler çocuk yetiştirirken kendi varoluşunu çocuk üzerinden yeniden modelleyebilmektedir. $\mathrm{Bu}$ yeniden modellemede uyum varsa, arzu doyumu sağlanmaktadır ki hemşirenin sözleri de bunu desteklemektedir. Helen'in bebek doğurmaktan mutlu olmamasını anla- 
ması üzerine "Söyleyecek bir şey yok" (Treadwell, 1993, s. 27) demesi Helen' in konuşmasa bile çevresinin etkisine maruz kaldığını göstermektedir.

George çiçeklerle içeri girerek Helen' in doğum sırasındaki çığlıklarını duyduğunu, neler yaşadığını anladığını; kendisinin de zor zamanda çöküğünü fakat toparlandığını, Helen'in de aynını yapması gerektiğini söyler. Burada George’un yine empati kuramadığını görmekteyiz. Doğum yapmayı kendi deneyimiyle bir tutmaktadır. Tamamen farklı zorluklar olmasına rağmen bu yaklaşımı sergilemesi, hem 'kadın' olmanın ne demek olduğuyla ilgili bir fikri olmadığını gösterir hem de daha net olarak, klasik 'Amerikan Rüyası'nın 'Düşsen de hemen kalkabilirsin. Mühim olan güçlü olmak, ayakta kalmak' faraziyesinin bir sonucudur.

George odadan çıkar, sahneye doktorlar girer. Bu sahne ekspresyonist metnin feminist yönünü daha farklı bir açıdan ele almaktadır. Zar zor konuşan, kendini ifade edemeyen Helen, hemşire ile bağ kurmaya çalışırken, doktorlar neden hala bebeği beslemediğini sorduğunda, cevap verecek hemşireyi sustururlar ve "Şu modern nevrotik kadınlar, peh!” (Treadwell,1993, s. 29) diyerek, hem Helen'in psikolojisini görmezden gelmiş hem de hemşireyi susturarak kadının ifade ve bilgisini hiçe saymışlardır. Kısaca erkeklik söylemi olarak tanımlanan baskın erkek egemen yaşam biçimi görünür kılınmaktadır. Baskın gücün hükümran tavrının cinsiyet üzerinden verilmesiyle oyunun feminist yönü daha da belirginleşmektedir.

Helen odada yalnız kalınca sonunda konuşmaya başlar. Parçalı bir konuşma hakimdir. "Bırakın yalnız kalayım [...] Yeterince boyun eğdim. Daha fazla boyun eğmeyeceğim! [...] Herkes tanrıyı sever [...] Kötü de olsa severler [...] Elleri şişman da olsa [...] Sevmelidir. Bırakın dinleneyim [...] Dinlenemiyorum [...] A ğırlık gitti [...] İçimdeki ağırlık gitti [...] Daha fazla boyun eğmeyeceğim [...]” (Treadwell, 1993, s. 31) sözleri tanrı ile George arasında kurduğu bağı göstermektedir. Şişman elleri de olsa, kötü de olsa sevilmesi gereken tanrı ile George'un eşleşmesi yapılmıştır. Çünkü toplumdaki erkek egemen yap1, kocayı tanrılaştırmaktadır. Bu tanrılaşma, her istenildiğinde boyun eğen kadınlar yaratmaktadır. Fakat Helen bu kadınlardan birine dönüşemez. Toplumla çelişkisi tüm bu sarılıp sarmalanmışlığının çatışmasıdır.

Ayrıca bu sahne, günümüzde incelendiğinde özel bir anlamı da vardır. Treadwell daha o zamandan bu çelişkiyi yansıtabilmiştir. Bu doğum sonrası depresyon ${ }^{5}$ durumu başta, an-

5 Bebeği istememeye varabilecek bunalım. 
nelik mefhumunun kadında sorgulanmasıyla yargılansa da zaman içinde böyle bir depresyonun varlığı, doğumun ve anneliğin sadece mutluluk ile eşleşemeyeceği bilgisi ortaya çıkmıştır. Artık doğum sonrası depresyonunun, her türlü bebeğe ya da kocaya dair olumsuz duygulanıma neden olabilecek bir süreç olduğu kabul görmektedir.

\section{Bölüm-5: Yasak (Prohibited)}

Barda geçen bu bölümde üç masa vardır. Ses, elektronik piyanodan gelmektedir.. Bardaki her masada gizli konuşmalar dönmektedir. Çünkü bu masalarda oturanlar, dönemsel (1920’ler) olarak yasa dışı ya da ahlak dışı karakterlerdir. Bir masada olgun adam, genç adamı ilişki yaşamaya ikna etmeye çalışmakta, diğer masada bir adam, kadını yasa dışı olan kürtaja ikna etmeye çalışmaktadır. Üçüncü masada ise Bay Roe, Bay Smith ile oturmakta ve adamın sevgilisinin getireceği arkadaşıyla tanışmayı beklemektedir. Karısını aldatan Mr. Smith, bu bara gelerek modern dünyanın sunduğu düzeni delmekte ve saat altıda da evde olmayı ummaktadır. Aldatmaya bu kadar heveslenen adamın evliliğe de bu kadar bağlı olması çelişkidir. Adamların buluşacağı kadınlar, birinci sahnede ofiste gördüğümüz sekreter kız ile Helen'dir. Bay Smith'in sekreter kız ile ilişkisi vardır. Helen'in geliş sebebi de bellidir: Kocasının egemenliğinden sıyrılıp kendi özgürlüğüne kavuşabilmek. Bay Roe ile de iyi anlaşırlar. Adam tutsak düştüğü Meksikalılardan, onları öldürerek nasıl kurtulduğundan bahseder. Elini Helen'in eline dokundurunca, Helen bundan memnun olur. Kocasının dokunuşunun tam tersi bir duygu hisseder. Adamın evine gitmeye karar verirler. Bu aynı zamanda Helen'in, kocası dışında tanımlanabilir bir varlık olduğunu, varoluşunu benliğinde hissedebilmesi için yaptığı bir eylemdir.

Yan masadaki kürtajla ilgili konuşmada ise adamın kadına, doğurursa işi bırakması gerekeceği için kürtaj olması konusundaki 1srarı görülür. Burada ilk sahnede sunulduğu gibi, duygusal bütünlüğü tehdit edecek olan her zaman, kapitalist düzen içindeki maddi ihtiyaçtır. Kadının ruhsal bütünlüğü çocuk doğurmakla düzenlenecekken, sosyal düzenin acımasız çark1, parayı çocuğun önüne geçirmektedir.

\section{Bölüm-6: Mahrem (Intimate)}

Karanlık bir odada, dışarıdan gelen donuk ve düzensiz bir laterna sesi hakimdir. Helen sakindir. Adamdan etkilenmiştir. Özgürlüğüne düşkün bir adam olan Bay Roe, bir gün yoluna devam edeceğini söyler. Yani her zaman orada kalmayacaktır. Bu bir anlamda, alttan alta Helen'e kendisine bağlanmaması konusunda bir uyarı özelliği de taşımaktadır. 
Dışarıdan gelen İspanyolca şarkının anlamı üzerine bir konuşma geçer. Âşıkların birbirine hitap şekli olan "Küçük Cennetim” (Treadwell, 1993, s. 46) adlı bir şarkıdır bu. İnsanın İspanya gibi yerlere gidince özgürleştiğini söyleyen adama Helen'in tepkisi, kendisinin hiçbir zaman öyle yerlere gidemeyeceğini söylemesiyle karşılık bulur. Sahne oldukça romantiktir. İspanyol şarkısı, laterna sesi, Helen'in sakinliği, adama olan ilgisi, uçarı bir adam olan Bay Roe'nin cazibesi. Peki Treadwell neden böyle bir sahneyi, karanlık, köhne bir odada ve ayak manzaralı bir evde yazmayı tercih etmiştir? İnsanlar gelip geçerken pencereden ayakları görünmektedir. Yerin altında bir evdir burası. Bu, Helen'in özgür olmaya duyduğu özlemi belirtse de, aslında bir yandan sıkışmışlığını simgeler niteliktedir. Bu, sahnenin görünen kısmıdır. Halbuki Bay Roe bu cazibesinin altında Helen'e, “çocuk” (Treadwell, 1993, s. 47) diye hitap etmektedir. Etkilenilen bir kadına 'çocuk' demek aslında konum olarak onu küçümsemektir. Bağlanmayı istememesi, olaya gecelik bir ilişki olarak baktığını göstermektedir. Atmosfer ise romantik bir karabasan gibidir. Bireyselliği, özgür iradeyi görünür kılması açısından Bay Roe önemlidir fakat; o da kadına yaklaşımı açısından, kadını zevk objesi olarak değerlendirmektedir. İki adam (George ve Roe) da kendilerini otoriter, kadını ise bağımlı görmektedir. Kendilerini bağımsız gören bu adamlar, kadına sadece haz odaklı yaklaşarak, her seferinde erkekliğin yeniden baskın söylem olarak inşa edilmesinin ötesine geçememektedir.

Helen, sarmaş dolaş yaşadığı cinsel bir anın sonrasında, özgür irade sembolü olarak gördüğü Bay Roe'nin evinden çıkarken, evdeki leylağı ister. Bu, Helen'in bilinçaltı libidinal $^{6}$ yatırım yaptığ 1 doyumunun nesnesidir.

\section{Bölüm-7: Ailevi (Domestic)}

Evin oturma odasında Helen ve George karşıllklı oturmakta ve yüksek sesle gazete başlıklarını birbirlerinden bağlantısız bir şekilde okumaktadır. George'un okudukları "Rekor üretim [...] İndirim bir milyonu vurdu [...] Pazar istikrarı” (Treadwell, 1993, s. 53) gibi başlıklar iken, Helen'in okudukları "Genç kız gazı açtı [...] Aşk için terk eden kadın [...] Genç zevce kayboldu” (Treadwell, 1993, s. 53) gibi başlıklardır. George'un ilgisini çeken başlıklar ekonomiye dairken, Helen'inkiler en üzücü kadın hikâyeleridir. George, genel erkek kimliğinin maddiyat üzerinden kurulmasının figürüyken, Helen yaşamın çepeçevre sardığı sıkışmış hayatlarına farklı çözümler bulan kadınların temsilcisidir. İntihar eden, terk eden, kaybolan kadınlar. Oyun boyunca kadınlık ve erkeklik faraziyelerinin yeniden

6 "Yaşam ya da cinsellik içgüdüsü” anlamındaki psikanalitik kavram (Burger, 2006, s. 80). 
üretimi, anlatılmış düşüncenin yeniden sunulması, Treadwell tarafından yaratıc1, ilgi çekici bir yapılandırma ile gazete başlıkları okuma üzerinden verilmektedir. Birbirlerini dinlemeden parçalanmış bir konuşma, ekspresyonist uygulamanın bir örneğidir.

George'a gelen telefonların hepsinde hemen hemen aynı konuşmayı yapması; konuşmaların aldığı mülk, atılan imza üzerine olması, onun hayatını inşa ettiği maddi yaşamın dönüştürdüğü mekanik bireyi yansıtmaktadır. Aynı zamanda bu mülkü üç ipotekle almasına rağmen sanki borçlanmamış̧̧asına sevinmesi kapitalist sistemin, daha iyisini arzulamayı sağlayarak amacın bireyin borçlanması ve daha iyiyi elde etmekle borçlandığını kanıksaması üzerine mekanikleşmiş düşünüş biçimini de sergilemektedir.

Helen ise amaçsızca ardı ardına "Mülkü aldın mı? [...] İmza atıldı mı?" (Treadwell, 1993, s. 53) gibi sorular sormaktadır. Adeta ruh ölümü gerçekleşmiş bir kadındır. Kocası ona dokununca, yine geri çekilir. Fakat George, bu geri çekilmeleri başından beri, Helen'in masumiyetine ve saflığına bağlamaktadır. Dokunmasının Helen'i tiksindirdiğinin farkında bile değildir. Çünkü kadın onun gözünde pirüpak, çekinen, mahfuz bir varlıktır. Onun sosyal mefhumu budur. O yüzden kendisinden tiksinebileceği dahi aklına gelmemiştir.

George'un, kendi gibi bir damada sahip olduğu için Helen'in annesinin şanslı olduğunu belirtmesi ve Helen'in "mücevher ve değerli taşlarda indirim" (Treadwell, 1993, s. 56) başlığını okuması sonucu Helen ögürür, boğulma hissi gelmiştir. Sanki taşlar boynunda gezmektedir. $\mathrm{Bu}$, aynı zamanda bir eş, anne olarak yüklenen sorumluluklar altında ezildiğinin de göstergesidir. Maddi rahatllğ 1 olacak bir hayat seçmiş fakat; manevi ölümüne yol açmıştır. Benliği paramparça bir hale gelmiştir.

Kocas1 ise bu boynunda taş gezme hissinin, Helen'in hayal gücü olduğunu söyler ve kendisinin asla bir şey hayal etmediğini dile getirir ki bu doğrudur. George hiçbir zaman hayal etmez. Eyler. Ancak bu George'un olumlu bir özelliği değildir. Gerçekçiliğinden ziyade mekanikleşmesinin sonucudur. Duygu ve hayal, 'makine' ile bağdaşmayan kavramlar olduğundan, George ile özdeşleştirilerek, onun makineye dönüşen benliği sunulmaktadır. Sahnenin sonunda, dışarıdan gelen konuşma sesleri Roe'nin anlattı $\breve{g}$, Meksikalıları öldürürken kullandığı pet şişeye doldurduğu taşları anımsatır. Bir sanrı gibi "Taşlar - taş -küçük taşlar - doldurulan taşlar - soğuk taşlar - baş taşları" (Treadwell, 1993, s. 59) sözleri inlemektedir. Taşlarla ilgi sanrısal sayıklamalara küçük cennetim şarkısının eşlik etmesi, öldürme dürtüsünün bilinçaltı temsilidir. 


\section{Bölüm- 8: Kanun (The Law)}

Helen'in kocası George ölmüştür ve Helen tutuklu olarak yargılanmaktadır. Bu sahnede Helen'in mahkemesi görülmektedir. İfadesi: 2 Haziran gecesi, yataklarının kocası tarafında iki adam görmüştür ve kocasının kafasına bir şey indirmişler, George kendini toparlamaya çalışırken tekrar indirmişler ve orada ölmüştür.

Bunun üzerine iki muhabir, mahkeme salonunda yüksek sesle not alır. Biri "Bayan Jones hikâyeyi doğrudan anlattı" (Treadwell, 1993, s. 66) diğeri, "Hikâyeyi dolandırarak anlattı" (Treadwell, 1993, s. 66) diye not alır. Basının birebir gördüğü olaylar karşısındaki yorum farkını göstermek ve böylece insanlar üzerindeki manipülatif etki görünür kılınmak istenmiştir. Basın aracılığı ile hiçbir şey gerçekte olduğu gibi algılanamaz. Gerçeğin bir aktarımıdır ve aslında ekspresyonizmde yer alan öznenin ifadesi ve bunun gerçekle ilişkisinin toplumsal düzeydeki, en bariz haber alma özgürlüğünün dahi çarpık yapısını sunmaktadır.

Mahkemede savunma avukatı, savunmasını George ve Helen'in evliliklerinin mutluluğu ve düzenliliği üzerine kurmuştur. Altı yılda hiç kavga etmemeleri, beraber yatıyor olmaları, George’un maddi olarak annesini desteklemesi gibi dayanaklar sunar. 'İyi insan’ olarak tanımlanabilmek, toplumsal düzeni yürüten kurumların işlemesine ne denli katkıda bulunulduğu ile ölçülmektedir.

Dava avukatı ise Helen'in, George'a olanlar sırasında bir şey yapmaması ve odanın karanlık olduğunu söylemesine rağmen, George'un yaralandığını gördüğü ifadesinin çelişkisine odaklanmaktadır. Oyun boyunca söyledikleri göz ardı edilen Helen'in şu anda ağzından çıkan tek bir kelime bile önem kazanmıştır. Yok sayılan sözleri şu anda tane tane analiz edilmekte ve kendisine karşı bir silah olarak kullanılmaktadır.

Dava avukatı, Helen'in bir yıl önce eldiven giymeye başlaması ile tekrar vücudunun en güzel bulduğu uzvu olan ellerine dikkat etmesini, kocasını aldattığının kanıtı sayar. Polisi aramak yerine önce geceliğine bulaşan kanı yıkamış olmasına ve şişe içindeki leylak ile taşlara değinir. Sonunda da Bay Roe'nin Helen ile olan ilişkisini anlattığı mektubunun okunması ile Helen, George'u öldürdügünü itiraf eder. Sunulan maddi kanıtlar karşısında direnebilen Helen, evlilik dışı ilişkisinin ortaya çıkmasına dayanamayıp bu itirafı gerçekleştirmiştir. "Madem özgür olmak istiyordunuz, neden boşanmadınız da kocanızı öldürdünüz?" (Treadwell, 1993, s. 75) diye sorulduğunda ise "Bunu yapamazdım. Onu bu şekilde incitemezdim" (Treadwell, 1993, s. 75) diye cevaplar. Sadece özgür olmak için 
öldürdüğünü belirtir. İnlemektedir, dağılmıştır. Özgürlüğünü hissetmek için bir y1ldır görüştüğü Bay Roe da ona karşı duygusal his beslemediği için bu mektubu yazıp mahkemeye yollamıştır. Helen'i ele veren ve dağıtan, yine aile kurumunun gereklerini yerine getirmemesidir. Toplumsal kurumlara uygun hareket etmeyenler dağılmaya her zaman mahkûm olacaktır. Bu, kadın algısının çok sağlam bir ekspresyonist ifadesidir.

Muhabirlerin de son olarak yazdığı ortak yazı Helen'in suçlu olduğudur. Makine sistem, sadece bir defa tam randıman ve ortak işler hale gelmiştir. O da Helen'e karşı olan birlikle mümkün olmuştur.

\section{Bölüm-9: Bir Makine (A Machine)}

Daktilo sesi, siyahi bir adamın şarkısı ve uçak sesi arka planı oluştururken, Helen ile rahibin hapishanedeki konuşmasına şahit oluruz. Helen, siyahi adamın ruhani şarkısını dinlemek istemektedir. Burada bir çelişki oluşturulmuştur. Helen siyahi adamın şarkısını anlamakta ve kendisi gibi hüküm giydiği için bütünleşebilmektedir. Bu, siyahilerin yaşadıkları insanlık dışı muamele ile kadınların ikincilleştirilmesi arasında fark olmadığını gösterir. Aynı zamanda hikâyeye ruhani yardım için dahil edilen rahibin söyledikleri ise Helen'e hiçbir etki yaratmamaktadır. Rahip de bir geleneğin ürünü olarak oradadır. Anlattıklarının kazıdığı bir gerçek yoktur. Helen için anlamsızdır. Siyahi adamın şarkısı ise durumunu gözler önüne serer. Öldürmeden ziyade sosyal parçalanmışlı̆ga ve adaletsizliğin yeni kurbanlar üreten nosyonuna göndermedir.

Helen'in elektrikli sandalyeye götürülmeden önce saçının kazınmasının gerekliliği, onun bir başka çığlığına yol açar. Helen "Boyun eğmeyeceğim” (Treadwell, 1993, s. 79) der. "Bu saygısızlık. [...] Her zaman boyun eğdim [...] Artık ölüme gidiyorum. Bu sefer boyun eğmeyeceğim” (Treadwell, 1993, s. 79). Başından sonuna bireyselliğini sergileyemeyip boyun eğen Helen, ölümünde buna karşı çıkmak ister fakat; yine çıkamaz. Düzen, ölüme giderken bile işlemektedir. Düzen saçının kesilmesini buyurmaktadır ve berberin de dediği gibi başından sonuna boyun eğmek zorundadır.

Geçen uçağın gölgesinin vurması ile Helen'in "Bak peder! Bir adam uçuyor. Kanatları var ama bir melek değil” (Treadwell, 1993, s. 80) yorumu, özgürlüğün duygusal bir fenomen olduğunu ancak; makine dünyasına ayak uydurmakla, uydurma bir özgürlükten bahsedilebileceğini göstermektedir. Bu duygu da illaki geçici olacaktır. Çünkü bu sosyal düzende insan saçlarının bile sahibi değildir. 
Son olarak annesiyle görüşmek istemez, gardiyanlar alır ve Helen'i ölüme götürür. Rahibin duaları ile habercilerin yorumları birbirine karışırken Helen'in balayı odasındaki çığlığının aynısı duyulur: "Biri! Herhangi biri" (Treadwell, 1993, s. 83). Sesi kesilir. Oyunda defalarca, George, Bay Roe, doktor, avukat, annesi, iş arkadaşları tarafindan kesilen sesi, son olarak elektrikli sandalye tarafından kesilmiştir. Treadwell burada, sosyal yaşama uymak için kadınlara biçilenin makineye dönmek, makine gibi verilen talimatlarla eylemek olduğunu son kez görünür kılar. Aksi halde büyük makine sesini tamamen kesecektir.

\section{Sonuç}

Sophie Treadwell'in Machinal oyunu, makineleşmiş insan tasviri yapar. Hatta sahnede (özellikle ofis sahnesinde) makine şeklinde eyleyen insan sunumuyla, toplumsal yapının kurduğu düzenin, insanı makine gibi talimatlarla çalışmaya ittiğini gösterir. Aksi halde kurumların işlemesine engel olan kişi toplumda barınamaz. Kadınlık, erkeklik, cinsel birliktelik, aile, annelik, adalet sistemi ve iş yaşamı, insanı özellikle de kadını, çerçevesi belirlenmiş eylemlere hapseden ideolojik aygıtlardır.

Oyun, ekspresyonist tiyatronun yapısı gereği, birçok yerde parçalı konuşma biçemini düstur edinmiştir. Kullandığı mekanik seslerle atmosfer perçinlenmiş, dilin engelleri gözler önüne serilmiştir. Birinci sahnede, ofis çalışanlarının birbiriyle bağlantılı olmayan konuşmaları ve mekanik hareketleri gerçeklikten kopuşa bir örnektir. Çalışanlar, kendi işlerinden başka bir şey düşünmemektedir. Sadece, Helen'le ilgili dedikodu yaptıklarında ortak bir konu üzerinde konuşurlar fakat; bu konuşmanın da yapısı parçalanmıştır. Çalışanların, insanî ilişkilerini bir tarafa bırakmaya iten iş hayatını görünür kılmaktadır. İş arkadaşları çalışırken, Helen'in yüksek sesle, kesik kesik sayıklamaları ve kimsenin buna tepki vermemesi de yine gerçekliği bozan bir unsurdur. İş hayatında dinlenmeye yer olmadığını gösterir. İkinci sahnede Helen, sadece evlenme teklifi aldığını söylediğinde annesiyle iletişime geçebilmektedir. Evlilik bu sahnede, kadın için, bir erkeğin maddi koruyuculuğu altına girmekten farklı bir kurum olmadığını açığa çıkarmaktadır. Çünkü annesi aynı zamanda aşk ile evliliği bağdaştırmanın beklendiği gibi sonuçlar doğurmayacağını düşünmektedir. $\mathrm{Bu}$, metinde farklı cümlelerle ifade edilse de, sahne sonunda anne ve kızının konuşması devam ederken bir anda kar1-koca seslerinin duyulmasıyla yine gerçeklik sekteye uğrar. Diyaloğun akışı bozulmuş ve düşüncenin ön plana çıkması güçlenmiştir. Üçüncü sahnede, gerçekliği bozacak biçimsel bir tekniğe rastlanmamıştır. Evliliğin cinsel birleşim için ye- 
terli görülmesi sorgulanmıştır. Helen'in sahne sonundaki bağırışları, ekspresyonist sanatın ' çı̆̆glık' niteliğiyle bağdaşmaktadır. Dördüncü sahnede annelik mefhumu sorgulanırken, doğum sonrası depresyon anlatılmaktadır. Sahnede biçimsel bir farklılığa rastlanmaz. Treadwell sahneyi, yine sayıklamalarla sona erdirmiştir. Ancak Helen bu sayıklamalar sırasında yalnızdır. Gerçekliği bozucu bir unsur değildir. Sadece 'çı̆̆lık' düsturu yinelenmiștir. Beşinci sahnede biçimsel bir ekspresyonist unsura rastlanmamıştır. Kürtaj, aldatma ve eşcinsellik kavramları sorgulanmıştır. Bunun için mekân olarak izbe bir bar seçilmiştir. Mekânın bayağılığıyla, üç ayrı masada oturan karakterlerin toplumda ahlak dışı olarak nitelendirildiği bağlantılanmak istenmiştir. Üç ayrı masada konuşulanlar, kendi içinde bütünlük arz eder. Altıncı sahnede de farklı bir biçim yoktur. Aldatma kavramı sorgulanmaktadır. Kocasıyla cinsel ilişkiye girmek istemeyen Helen, yeni tanıştı̆̆ bir adamla birlikte olmaktadır. Cinsellik için ilişkinin resmiyete dökülmesi bir faraziyedir. Evlilik üretilmiş bir kurumdur. Fakat bu düşünceler gerçekçi bir üslupla anlatılmıştır. Yedinci sahnede Helen ve kocası, yüksek sesle gazete başılılarını okumaktadır. Birbirlerine tepki vermezler. Kocası ekonomi, Helen ise kadın içerikli başlıkları okur. Aralarında iletişim yoktur. İletişime geçtiklerinde ise kocasına gelen telefonlar, iletişimi sekteye uğratır. Çünkü maddiyat yaşamda her şeyin üstündedir. Sahne sonunda yankılanan seslerde ise Helen'in iç dünyasına, ekonomi haberlerinin sesleri karışır. Maddiyatın yaşamda başat olması ve kadınlık ile erkeklik sorgulamaya açılırken, haber başlıklarının yüksek sesle okunması, oyunda daha önce de değinilmiş konuların, özgün bir biçimde sahnelenmesine olanak sağlamaktadır. Sekizinci sahnede medyanın manipülatif haber yapması, muhabirlerin mahkemede yüksek sesle not almalarıyla gösterilmiştir. Çünkü, bu notlar birbirinden farklıdır ve muhabirlerin kişisel yorumlarına dayanmaktadır. Mahkemede muhabirlerin yüksek sesle not alması, gerçekte mahkeme kurallarına aykırıdır. Bu kurala uymayan muhabirlere ise kimse tepki vermez. Olağan bir durum gibidir. Helen ise erkekler tarafindan sorgulanmakta ve yargilanmaktadır. Adalet sistemi, Helen'e karşı bir birlik oluşturmuştur. Toplumsal yapı, Helen'e kocasını öldürmekten başka çare bırakmamıştır. Helen'i cinayete iten de cezalandıran da bu yapıdır. Dokuzuncu sahnede, rahibin duası, siyahi adamın şarkısı, Helen'in sayıklamaları ve muhabirlerin manşetleri birbirine karışmaktadır. Sözler birçok zaman birbirinden bağımsızdır. Helen'in iç dünyasını yansıtan bu sahne, aynı zamanda sistemin dışında davranış sergileyenlerin cezalandırılacağını görünür kılar. Birey, sisteme boyun eğmek zorundadır.

Machinal oyununda, öznel ifade, oyunun her sahnesinde düşünceye hizmet edecek şekilde işlenmiştir. Her sahneye belli bir sesin hakim olması, oyunun ritminin, sahne sahne 
farklılıklar göstermesi gerektiğini belirtir. Bazı sahneleri gerçekçi tiyatro özellikleriyle yazılmış olsa da oyunun bütünündeki ekspresyonist yapısını bozmaz. İnsanın varoluşunu feminist perspektiften sorgulayan bir ekspresyonist metin örneğidir. Oyunu, Türkiye sahnelerinde de görebilmek için, bu çalışmanın ilham kaynağı olabilmesi umulmaktadır.

\author{
Hakem Değerlendirmesi: Dış bağımsız. \\ Çıkar Çatışması: Yazar çıkar çatışması bildirmemiştir. \\ Finansal Destek: Yazar bu çalışma için finansal destek almadığını beyan etmiştir. \\ Peer-review: Externally peer-reviewed. \\ Conflict of Interest: The author has no conflict of interest to declare. \\ Grant Support: The author declared that this study has received no financial support.
}

\title{
Kaynakça/References
}

Burger, J. M. (2006). Kişilik (İ. D. Erguvan Sarığlu, Çev.). İstanbul: Kaknüs Yayınları.

Bywaters, B. L. (1990). Marriage, madness and murder in Sophie Treadwell's Machinal. In J. Schlueter (Ed.), Modern American Drama: The Female Canon. Rutherford, NJ: Fairleigh Dickinson University Press.

Dickey, J. (1997). The 'Real Lives' of Sophie Treadwell: Expressionism and feminist aesthetic in machinal and for saxophone. In J. C. Reesman (Ed.), Speaking the Other Self: American Women Writers. Athens: University of Georgia Press.

Dickey, J. (1999). The expressionist moment: Sophie Treadwell. In B. Murphy (Ed.), American Women Playwrights. Cambridge: Cambridge University Press.

Jones, J. (1994). In Defense of the woman: Sophie Treadwell's machinal. Modern Drama, 37(3), 485-496.

Moran, B. (2014). Edebiyat kuramları ve eleştiri. İstanbul: İletişim Yayınları.

Richard, L. (1999). Ekspresyonizm sanat ansiklopedisi (B. Madra, S. Gürsoy, İ. Usmanbaş, Çev.). İstanbul: Remzi Kitabevi.

Smith, R. J. B. (1987). The influence and effect of german expressionist drama on theatrical practice in britain and the United States 1910-1940 (Doctoral dissertation, Royal Halloway and Bedford New College, University of London, London). Retrieved from https://repository.royalholloway.ac.uk/items/029505a4-509f-4f19-a34f$48048816 \mathrm{~d} 96 \mathrm{~b} / 1 /$

Şener, S. (2008). Dünden bugüne tiyatro düşüncesi. Ankara: Dost Kitabevi.

Tancheva, K. (2003). Sophie Treadwell's play machinal: Strategies of reception and interpretation. In A. Gewirtz \& J. J. Kolb (Eds.), Experimenters, Rebels and Disparate Voices: The Theatre of the 1920s Celebrates American Diversity (pp. 10-110). Westport-Connecticut: Preager.

Treadwell, S. (1993). Machinal. London: Nick Hern Books. 
